\title{
ERRATUM
}

Ada Kritikos • Michael Beresford

\section{Tactile interference in visually guided reach-to-grasp movements}

Published online: 20 March 2002

(C) Springer-Verlag 2002

\section{Exp Brain Res (2002) \\ DOI 10.1007/s00221-002-1004-1}

Umberto Castiello has notified Springer-Verlag and the Editors that his name was included in the article by error. The correct authorship is as follows:

Ada Kritikos and Michael Beresford

The online version of the original article can be found at http://dx.doi.org/10.1007/s00221-002-1004-1

A. Kritikos $(\varangle) \cdot$ M. Beresford

School of Behavioural Science, Department of Psychology,

University of Melbourne, Victoria 3010, Australia

e-mail: a.kritikos@psych.unimelb.edu.au

Tel.: +61-3-83444453, Fax: +61-3-93476618 